\title{
Blood Pressure and Risk of Atrial Fibrillation: A Mendelian Randomization Study
}

Matthew C. Hyman, MD, $\mathrm{PhD}^{1} *$; Michael G. Levin, $\mathrm{MD}^{1,2}$; Dipender Gill, BMBCh, $\mathrm{PhD}^{3-7}$; Venexia M. Walker, $\mathrm{PhD}^{8,9,11}$; Marios K. Georgakis, MD, $\mathrm{PhD}^{10}$; Neil Davies, $\mathrm{PhD}^{8}$; Francis E. Marchlinski, $\mathrm{MD}^{1}$ and Scott M. Damrauer, $\mathrm{MD}^{2,11}$

${ }^{1}$ Division of Cardiovascular Medicine, University of Pennsylvania Perelman School of Medicine, Philadelphia, PA

${ }^{2}$ Corporal Michael J. Crescenz VA Medical Center, Philadelphia, PA

${ }^{3}$ Department of Epidemiology and Biostatistics, School of Public Health, Imperial College

London, United Kingdom

${ }^{4}$ Centre for Pharmacology and Therapeutics, Department of Medicine, Hammersmith Campus, Imperial College London, London, UK.

${ }^{5}$ Department of Genetics, Novo Nordisk Research Centre Oxford, Old Road Campus,

Oxford, UK

${ }^{6}$ Clinical Pharmacology and Therapeutics Section, Institute of Medical and Biomedical

Education and Institute for Infection and Immunity, St George's, University of London,

London, UK

${ }^{7}$ Clinical Pharmacology Group, Pharmacy and Medicines Directorate, St George's University Hospitals NHS Foundation Trust, London, UK

${ }^{8}$ Medical Research Council Integrative Epidemiology Unit, University of Bristol, Bristol, United Kingdom 
medRxiv preprint doi: https://doi.org/10.1101/2020.07.26.20162339; this version posted July 29, 2020. The copyright holder for this preprint (which was not certified by peer review) is the author/funder, who has granted medRxiv a license to display the preprint in perpetuity. All rights reserved. No reuse allowed without permission.

${ }^{9}$ Bristol Medical School: Population Health Sciences, University of Bristol, Bristol, United Kingdom

${ }^{10}$ Institute for Stroke and Dementia Research (ISD), University Hospital, LudwigMaximilians-University LMU, Munich, Germany

${ }^{11}$ Department of Surgery, University of Pennsylvania Perelman School of Medicine, Philadelphia, PA

*These authors contributed equally to this work

\section{Word Count:}

\section{Corresponding Author:}

Scott M. Damrauer

University of Pennsylvania

2400 Spruce Street, Silverstein 4

Philadelphia, PA 19104

Phone: 215-615-1698

damrauer@upenn.edu 
medRxiv preprint doi: https://doi.org/10.1101/2020.07.26.20162339; this version posted July 29, 2020. The copyright holder for this preprint (which was not certified by peer review) is the author/funder, who has granted medRxiv a license to display the preprint in perpetuity.

All rights reserved. No reuse allowed without permission.

\begin{abstract}
Importance: Observational studies have shown an association between hypertension and atrial fibrillation (AF). Aggressive blood pressure management in patients with known AF reduces overall arrhythmia burden, but it remains unclear whether hypertension is causative for AF.

Objective: The primary objective of this study was to investigate the relationship between blood pressure and risk of AF using genetic proxies for blood pressure within a Mendelian randomization (MR) framework. We secondarily explored the relationship between genetically proxied use of anti-hypertensive drugs and risk of AF.
\end{abstract}

Design: Two-sample MR was performed using an inverse-variance weighted meta-analysis with weighted median MR and Egger intercept tests performed as sensitivity analyses. Genetic proxies for the anti-hypertensive drug classes were used to investigate the impact of these therapies on the risk of AF.

Setting: International Consortium of Blood Pressure, UK Biobank and Atrial Fibrillation Genetics Consortium.

Participants: Summary statistics for systolic blood pressure (SBP), diastolic blood pressure (DBP), and pulse pressure (PP) were obtained from the International Consortium of Blood Pressure and the UK Biobank discovery analysis (>750,000 individuals of European ancestry). 
medRxiv preprint doi: https://doi.org/10.1101/2020.07.26.20162339; this version posted July 29, 2020. The copyright holder for this preprint (which was not certified by peer review) is the author/funder, who has granted medRxiv a license to display the preprint in perpetuity.

All rights reserved. No reuse allowed without permission.

Summary statistics for AF were obtained from the 2018 Atrial Fibrillation Genetics Consortium multi-ethnic GWAS (>65,000 AF cases and >522,000 referents).

Exposure: Genetically predicted SBP, DBP and PP as quantified by risk scores.

Main Outcome: Odds ratio for AF per $10 \mathrm{mmHg}$ increase in genetically proxied blood pressure.

\section{Results:}

Ten $\mathrm{mmHg}$ increases in genetically proxied SBP, DBP or PP were associated with increased odds of AF (SBP: OR 1.17, 95\% CI 1.11-1.22, $\mathrm{p}=1 \mathrm{x} 10^{-11}$; DBP: OR 1.25, 95\% CI 1.16-1.35, $\mathrm{p}=3 \times 10^{-8}$; PP: OR 1.1, 95\% CI 1.0-1.2, $\left.\mathrm{p}=0.05\right)$. Ten mmHg decreases in SBP estimated by genetic proxies of anti-hypertensive medications showed calcium channel blockers (OR 0.66, 95\% CI 0.57-0.76, $\mathrm{p}=8 \times 10^{-9}$ ) and beta-blockers (OR 0.61, 95\% CI 0.46-0.81, $\mathrm{p}=6 \times 10^{-4}$ ) decreased the risk of AF.

\section{Conclusions and Relevance:}

Blood pressure-increasing genetic variants were associated with increased risk of AF, consistent with a causal relationship between blood pressure and AF. These data support the concept that blood pressure reduction through pharmacologic intervention, and specifically calcium channel blockade or beta blockade could reduce the risk of AF. 
medRxiv preprint doi: https://doi.org/10.1101/2020.07.26.20162339; this version posted July 29, 2020. The copyright holder for this preprint (which was not certified by peer review) is the author/funder, who has granted medRxiv a license to display the preprint in perpetuity.

All rights reserved. No reuse allowed without permission.

\section{Abbreviations}

AF - atrial fibrillation

BB - beta-blocker

CCB - calcium channel blocker

DBP - diastolic blood pressure

eQTL - Expression quantitative trait loci

LD - linkage disequilibrium

MR - Mendelian randomization

PP - Pulse pressure

$\mathrm{SBP}$ - systolic blood pressure 
medRxiv preprint doi: https://doi.org/10.1101/2020.07.26.20162339; this version posted July 29, 2020. The copyright holder for this preprint (which was not certified by peer review) is the author/funder, who has granted medRxiv a license to display the preprint in perpetuity.

All rights reserved. No reuse allowed without permission.

\section{Introduction}

Atrial fibrillation (AF) remains a leading contributor to cardiovascular morbidity and mortality worldwide. ${ }^{1,2}$ Observational studies have demonstrated an association between modifiable risk factors - specifically hypertension, obesity, alcohol consumption and obstructive sleep apnea - and a reduction in the arrhythmic burden of patients with known AF. ${ }^{3,4}$ Although linked observationally, it is unclear if modification of these risk factors may prevent new onset $\mathrm{AF}$.

Due to its high prevalence, hypertension is thought to be the single greatest contributor to the burden of AF. In population studies such as the Framingham Heart Study and Atherosclerosis Risk in Communities, up to $20 \%$ of AF cases are attributed to pre-existing hypertension. ${ }^{5,6}$ Furthermore, $60-80 \%$ of patients with known AF have comorbid hypertension. ${ }^{7}$ Despite these observations, initiation of blood pressure lowering therapy was not associated with a clear reduction in AF burden in the Framingham cohort. ${ }^{8}$ Similarly, a randomized comparison of the angiotensin converting enzyme inhibitor, ramipril, versus placebo failed to demonstrate a relationship between ramipril therapy and incident $\mathrm{AF}^{9}$ Secondary analyses in other studies comparing hypertensive agents (angiotensin converting enzyme inhibitors, beta-blockers, calcium channel blockers and diuretics) have not demonstrated a consistent benefit of one antihypertensive regimen over another for reducing AF. ${ }^{10-12}$ Comparisons of intensive blood pressure lowering with standard blood pressure lowering have suggested a benefit for patients with hypertension and elevated risk of cardiovascular events, but not hypertension and diabetes. ${ }^{13,14}$ The inconsistent findings of anti-hypertensive therapy studies and observational studies has led some to question the strength of the direct relationship between blood pressure and $\mathrm{AF}$ or argue that it is driven by isolated subpopulations. ${ }^{15-18}$ 
Preventative studies on a population scale are difficult to accomplish in a randomized and adequately powered fashion with sufficient duration. To overcome this limitation, this study employed a population genetics-based approach within a Mendelian randomization framework to better understand the causal role of blood pressure on risk of AF. This technique takes advantage of the random allocation of blood pressure-associated genetic variants that occurs at conception. This random assortment minimizes the chance of environmental confounding, enabling investigation into the causal relationship between blood pressure and AF. We subsequently evaluated genetic proxies for the pathways targeted by anti-hypertensive medications to better understand potential class effects of anti-hypertensive medications on AF. 
medRxiv preprint doi: https://doi.org/10.1101/2020.07.26.20162339; this version posted July 29, 2020. The copyright holder for this preprint (which was not certified by peer review) is the author/funder, who has granted medRxiv a license to display the preprint in perpetuity.

All rights reserved. No reuse allowed without permission.

\section{Methods}

Study populations

For the primary analysis, summary-level data for genome wide association studies (GWAS) of hypertension and AF were used. ${ }^{19,20}$ Blood pressure data were obtained from the 2018 Evangelou et al. International Consortium for Blood Pressure + UK Biobank GWAS metaanalysis, which included systolic blood pressure, diastolic blood pressure, and pulse pressure measurements in up to 757,601 individuals. Summary statistics for blood pressure are publicly available, and were downloaded from the NHLBI GRASP catalog (https://grasp.nhlbi.nih.gov/FullResults.aspx). AF data was obtained from the 2018 Roselli et al. atrial fibrillation GWAS meta-analysis from the Atrial Fibrillation Genetics (AFGen) consortium study, including 65,446 AF cases and 522,744 controls. Summary statistics for AF were contributed by the AFGen consortium (http://afgen.org), are publicly available, and may be downloaded from the Variant to Function Knowledge Portal (http://www.kp4cd.org/datasets/v2f). Because both the blood pressure exposure and AF outcome studies included participants from UK Biobank (458,577 for BP and 351,017 for AF), bias due to sample overlap was estimated. $^{21}$

\section{Study exposures}

The 2018 Evangelou et al. International Consortium for Blood Pressure + UK Biobank discovery meta-analysis GWAS included up to 757,601 participants. This analysis included up to 299,024 European participants from 77 independent studies genotyped with various arrays and imputed to either the 1000 Genomes Reference Panel or the HRC platforms, and 458,577 participants from the UK Biobank. Blood pressure ascertainment varied among cohorts, and 
medRxiv preprint doi: https://doi.org/10.1101/2020.07.26.20162339; this version posted July 29, 2020. The copyright holder for this preprint (which was not certified by peer review) is the author/funder, who has granted medRxiv a license to display the preprint in perpetuity.

All rights reserved. No reuse allowed without permission.

study-specific details are presented in the supplemental material. ${ }^{19}$ For each BP trait, genetic variants associated with systolic blood pressure (SBP), diastolic blood pressure (DBP), and pulse pressure $(\mathrm{PP})$ at genome-wide significance $\left(\mathrm{p}<5 \times 10^{-8}\right)$ were identified and LD-pruned (distance threshold $\left.=10,000 \mathrm{~kb}, \mathrm{r}^{2}<0.001\right)$ using the 1000 Genomes European-ancestry reference panel to identify independent variants. Because the Evangelou et al. study adjusted effect estimates for body mass index potentially leading to introduction of collider-bias as body mass index is causal for both elevated blood pressure and AF, a sensitivity analysis was performed using systolic $(\mathrm{N}=$ $436,419)$ and diastolic $(\mathrm{N}=436,424)$ blood pressure genome-wide association study summary statistics from European UK Biobank participants adjusted for genotyping array, sex, and population structure. $^{22}$

\section{Primary outcome}

The AFGen consortium identified participants from more than 50 studies $(84.2 \%$ European, 12.5\% Japanese, 2\% African American, and 1.3\% Brazilian and Hispanic), including participants from the UK Biobank, Biobank Japan, other international biobanks, and international cardiovascular cohort studies (adjusted for age, sex, and study-specific covariates). AF ascertainment was study-specific, including diagnostic codes, electronic health record information and self-report.

\section{Study design}

The primary analysis estimated the effect of blood pressure on risk of AF using twosample Mendelian randomization with an inverse-variance weighted model with random effects. The MR-Egger bias intercept test was used to identify the presence of bias from directional 
medRxiv preprint doi: https://doi.org/10.1101/2020.07.26.20162339; this version posted July 29, 2020. The copyright holder for this preprint

pleiotropy. Sensitivity analysis was performed using weighted median MR and Egger intercept tests, which are more robust to the presence of invalid genetic instruments. ${ }^{23}$

Recent work has demonstrated that genetic proxies can be used to estimate the effect of individual anti-hypertensive drug classes on clinical outcomes using a Mendelian randomization framework. ${ }^{24,25}$ We used two approaches to estimate the effect of blood pressure lowering medication on risk of $\mathrm{AF}$ :

1) Genes encoding the targets of anti-hypertensive medications (angiotensin-converting enzyme inhibitors, angiotensin receptor blockers, $\beta$-blockers, calcium channel blockers and thiazide diuretic agents) were identified using DrugBank and the GeneHancer database in the GeneCards platform (v4.7). ${ }^{24}$ SNPs were identified within corresponding genes, promoter regions, or enhancers that were associated with $\mathrm{SBP}$ at genome-wide significance $\left(\mathrm{P}<5 \times 10^{-8}\right)$ and clumped to a linkage disequilibrium (LD) threshold of $r^{2}<0.1$ using the $1000 \mathrm{G}$ European reference panel. These genetic variants were used as instruments to model the effect of lower SBP mediated by individual anti-hypertensive drug classes. The SNPs were then utilized to estimate the effect of the individual anti-hypertensive drug classes on risk of AF using twosample inverse variance weighted and median weighted Mendelian randomization as above.

2) Expression quantitative trait loci (eQTL) for protein targets of antihypertensive medications were used as a proxy for the action of a drug on its target (e.g. variants associated with angiotensin-converting enzyme gene expression as a proxy for the angiotensin converting enzyme inhibitor drug class). ${ }^{25}$ Twelve antihypertensive drug classes were considered: adrenergic neuron blocking drugs; alpha-adrenoceptor blockers, angiotensin-converting enzyme inhibitors, angiotensin-II receptor blockers, beta-adrenoceptor blockers, calcium channel blockers, centrally acting antihypertensive drugs, loop diuretics; potassium-sparing diuretics and 
medRxiv preprint doi: https://doi.org/10.1101/2020.07.26.20162339; this version posted July 29, 2020. The copyright holder for this preprint (which was not certified by peer review) is the author/funder, who has granted medRxiv a license to display the preprint in perpetuity.

All rights reserved. No reuse allowed without permission.

aldosterone antagonists, renin inhibitors, thiazides and related diuretics and vasodilator antihypertensives. SNPs were identified for the protein targets of each drug class using the GTEx project data (Release V7; dbGaP Accession phs000424.v7.p2), which contains expression quantitative trait loci analyses of 48 tissues in 620 donors. ${ }^{26}$ SNPs defined by GTEx as the variant with the smallest nominal p-value for a variant-gene pair were selected for analysis and validated as instruments by estimating their effect on systolic blood pressure using two-sample Mendelian randomization. SNPs with evidence of an effect on systolic blood pressure were used for the analysis.

\section{Statistical Analysis}

Two-sample Mendelian randomization was performed using the TwoSampleMR package in R (https://github.com/MRCIEU/TwoSampleMR). ${ }^{27}$ Variants associated with each blood pressure exposure at genome-wide significance $(\mathrm{p}<5 \times 10-8)$ were harmonized with the variants from the atrial fibrillation $\mathrm{GWAS}^{20}$, and LD-clumped (distance threshold $=10,000 \mathrm{~kb}, \mathrm{r}^{2}=0.001$ ) using the 1000 Genomes European ancestry reference panel, identifying a final set of independent single-nucleotide polymorphisms (SNPs) to use as a genetic instrument for blood pressure. Inverse variance weighted two-sample Mendelian randomization with random effects was used as the primary analysis with a weighted median analysis performed as a sensitivity analyses. ${ }^{28}$ For each variant included in the genetic instruments, the proportion of variance $\left(\mathrm{R}^{2}\right)$ in the phenotype explained was calculated using the formula $R^{2}=\frac{2 \beta^{2} M A F(1-M A F)}{2 \beta^{2} M A F(1-M A F)+2 N M A F(1-M A F) s e^{2}}($ where MAF represents the effect allele-frequency, beta represents the effect estimate of the genetic variant in the exposure GWAS, se represents the standard error of effect size for the genetic variant, and $\mathrm{N}$ represents the sample size). ${ }^{29} \mathrm{~F}$ - 
medRxiv preprint doi: https://doi.org/10.1101/2020.07.26.20162339; this version posted July 29, 2020. The copyright holder for this preprint (which was not certified by peer review) is the author/funder, who has granted medRxiv a license to display the preprint in perpetuity.

All rights reserved. No reuse allowed without permission.

statistics were then calculated for each variant using the formula $F=\frac{R^{2} \times(N-2)}{1-R^{2}}$ to assess the strength of the selected instruments. ${ }^{30}$ All statistical analyses were performed using $\mathrm{R}$ version

3.6.2.31. 
medRxiv preprint doi: https://doi.org/10.1101/2020.07.26.20162339; this version posted July 29, 2020. The copyright holder for this preprint (which was not certified by peer review) is the author/funder, who has granted medRxiv a license to display the preprint in perpetuity.

\section{Results}

Association of blood pressure with atrial fibrillation

We identified a set of independent variants to serve as instruments for systolic blood pressure $(n=399)$ and diastolic blood pressure $(n=398)$, and pulse pressure $(n=347)$ which accounted for $4.0 \%, 4.2 \%$ and $3.6 \%$ of the measured variability in these exposures, respectively (eTable 1-3). For the systolic blood pressure instrument, the mean F-statistic was 75 (range 30.4645.7). For the diastolic blood pressure instrument, the mean F-statistic was 79.9 (range 30846.6). For the pulse pressure instrument, the mean F-statistic was 76.4 (range 30.4-627.9). Bias due to sample overlap from UK Biobank participants included in both the blood pressure exposure GWAS and AF outcome GWAS was estimated to be negligible across a range of observational effect sizes: for example, at $100 \%$ sample overlap, bias was estimated to be 0.0003 for an observational odds ratio of 1.3 and 0.00069 for an observational odds ratio of 1.6 (eTable 4).

Two-sample Mendelian randomization using the above genetic instruments and inverse variance-weighted modeling demonstrated that each $10 \mathrm{mmHg}$ genetically predicted increase in systolic blood pressure, diastolic blood pressure and pulse pressure increased the risk of AF (SBP: OR 1.17, 95\% CI 1.11-1.22, $\mathrm{p}=1 \times 10^{-11}$; DBP: OR 1.25, 95\% CI 1.16-1.35, $\mathrm{p}=3 \times 10^{-8}$; PP:

OR 1.1, 95\% CI 1.0-1.2, p=0.05) (Figure 1). Results were similar in a sensitivity analysis using the weighted median method, with increased SBP, DBP and PP increasing risk of AF (SBP: OR $1.18,95 \%$ CI 1.12-1.23, p=5x10 ${ }^{-11}$; DBP: OR 1.24, 95\% CI 1.14-1.34, $\mathrm{p}=4 \times 10^{-7}$; PP: OR 1.11, 95\% CI 1.02-1.2, p=0.01) (Figure 1). The effects of SBP and DBP on risk of AF were also similar using alternative genetic instruments derived from UK Biobank (eFigure 1). 
medRxiv preprint doi: https://doi.org/10.1101/2020.07.26.20162339; this version posted July 29, 2020. The copyright holder for this preprint (which was not certified by peer review) is the author/funder, who has granted medRxiv a license to display the preprint in perpetuity.

All rights reserved. No reuse allowed without permission.

Genetically proxied blood pressure reduction through antihypertensive drug targets and atrial fibrillation

To estimate the effect of blood pressure reduction by different classes of anti-

hypertensive medications, we identified common genetic variants located within genes of protein targets of calcium channel blockers and beta blockers, as previously described. ${ }^{24}$ Twenty independent variants within protein targets of calcium channel blockers (CCBs) and 5 independent variants within protein targets of beta blockers (BBs) were associated with systolic blood pressure at genome-wide significance (eTable 5). When using these genetic proxies to estimate the effect of each $10 \mathrm{mmHg}$ decrease in systolic blood pressure by each antihypertensive drug class, genetically predicted protein targets of CCBs and BBs were associated with lower risk of AF (CCB: OR 0.66, 95\% CI 0.57-0.76, p=8x10-9; BB: OR 0.61, 95\% CI 0.460.81, $\mathrm{p}=6 \mathrm{x} 10-4$; Figure 2). In a complimentary analysis, we employed eQTLs for the protein targets of anti-hypertensive medications given genetic variants may exert their action via distant interactions (rather than via a true cis-acting association) (eTable 6). ${ }^{25}$ Using this technique, anti-hypertensive medication proxies reduced the risk of AF (CCB: SNP $n=23$, OR $0.66,95 \%$ CI $0.57-0.76, \mathrm{p}=8 \times 10^{-9} ; \mathrm{BB}: \mathrm{SNP} n=10, \mathrm{OR} 0.61,95 \%$ CI $\left.0.46-0.81, \mathrm{p}=6 \times 10^{-4}\right)$. There was not strong evidence of effect of other anti-hypertensive medication classes on AF risk (eTable 7). 
medRxiv preprint doi: https://doi.org/10.1101/2020.07.26.20162339; this version posted July 29, 2020. The copyright holder for this preprint (which was not certified by peer review) is the author/funder, who has granted medRxiv a license to display the preprint in perpetuity.

All rights reserved. No reuse allowed without permission.

\section{Discussion}

This study utilized Mendelian randomization to leverage population-level genetic information to explore the causal relationship between blood pressure and AF. The genetic determinants of elevated systolic blood pressure, diastolic blood pressure and pulse pressure were found to strongly associate with risk of AF; an association that persisted in statistical sensitivity analyses more robust to the inclusion of pleiotropic variants. Previously validated genetic proxies for the therapeutic effects of anti-hypertensive drug classes were used to estimate the impact of individual anti-hypertensive drug classes on incident AF, suggesting a potential role for anti-hypertensive medications in prevention.

A relationship between hypertension and AF has previously been established in observational analyses. ${ }^{5,6}$ These findings, however, were limited in demonstrating a causal role for hypertension in the development of AF due to the potential of residual confounding and reverse causation. ${ }^{15}$ This study sought to mitigate this risk of confounding by using genetic instruments randomly assorted in the population to proxy the effect of increased blood pressure traits on risk of AF. In doing so, we found that across all the considered measures of blood pressure (systolic blood pressure, diastolic blood pressure and pulse pressure), higher genetically proxied levels were associated with increased the risk of AF. These elevated blood pressure effects are directionally similar to those identified in observational studies and previous analyses using polygenic risk scores in smaller cohorts of patients further lending strength to the causal relationship between blood pressure and $\mathrm{AF} .{ }^{31-33}$

A variety of mechanisms have been proposed to explain how hypertension contributes to risk of AF. Animal models of hypertension have demonstrated the presence of left atrial scaring and inflammation. ${ }^{34-36}$ This scaring and fibrosis is thought to create altered patterns of 
medRxiv preprint doi: https://doi.org/10.1101/2020.07.26.20162339; this version posted July 29, 2020. The copyright holder for this preprint

conduction and functional slowing allowing for the development and perpetuation of $\mathrm{AF}$ triggers. $^{35,37,38}$ Concordantly, hypertensive animals have greater heterogeneity of atrial activation with increased susceptibility to AF induction. ${ }^{35}$ Other manifestations of left atrial remodeling such as increased left atrial size have been associated with hypertension and elevated systolic blood pressure in particular. ${ }^{39}$ It should be noted, however, that the impact of hypertension on AF risk persists after adjustment for left atrial size and mass. ${ }^{31}$

Beyond mechanism, this study explores the question of whether pharmacologic intervention may meaningfully impact a patient's risk of AF. While it would be ethically difficult to fully withhold anti-hypertensive therapy in a randomized trial, we leveraged genetic proxies to explore the impact of individual anti-hypertensive drug classes. Our study suggests that both calcium channel blocker and beta-blockers can significantly mitigate a patient's risk of developing $\mathrm{AF}$, though neither class was more effective than the other. There are inherent limitations to comparing genetic proxies for a lifetime of blood pressure lowering by an antihypertensive drug class to clinical trials that represent a limited duration of anti-hypertensive therapy. With that being said, our findings are consistent with clinical trials and case-control analyses that have not found consistent improvement in AF burden when beta-blockers and calcium channel blockers are compared to other drug classes including angiotensin-receptor blockers and angiotensin-converting enzyme inhibitors. ${ }^{11,12,40}$

\section{Limitations}

First, the GWAS of hypertension and AF were multiethnic, though the underlying studies were enriched with individuals of European ancestry. This may have skewed the risk estimates in our findings, and as such the analysis should be repeated in other populations before being 
generalized across ethnic groups. Second, this analysis estimates the lifelong effects of genetically predicted blood pressure reduction on AF risk and does not directly investigate effects of shorter-term alterations in blood pressure such as through pharmacological treatment in adulthood. Third, it should be noted that while the risk reduction of calcium channel blockers and beta-blockers was quantified in terms of $10 \mathrm{mmHg}$ blood pressure increments and in doing so assumes a linear model. Consequently, this study cannot answer the question of what level of blood pressure reduction maximizes AF risk reduction.

\section{Conclusions}

Blood pressure-increasing genetic variants were associated with increased risk of AF, consistent with a causal relationship between blood pressure and AF. These data support the concept that blood pressure reduction through pharmacologic intervention, and specifically calcium channel blockade or beta blockade could reduce the risk of AF. 
medRxiv preprint doi: https://doi.org/10.1101/2020.07.26.20162339; this version posted July 29, 2020. The copyright holder for this preprint (which was not certified by peer review) is the author/funder, who has granted medRxiv a license to display the preprint in perpetuity.

All rights reserved. No reuse allowed without permission.

Author Contributions: Drs Hyman and Levin contributed equally. Dr. Levin had full access to all of the data in the study and takes responsibility for the integrity of the data and the accuracy of the data analysis.

\section{Study concept and design:}

Hyman, Levin, and Damrauer.

Acquisition, analysis, or interpretation of data: Hyman, Levin, Gill, Walker, Georgakis, Davies and Damrauer.

Drafting of the manuscript: Hyman, Levin and Damrauer.

Critical revision of the manuscript for important intellectual content: Hyman, Levin, Gill, Walker, Georgakis, Davies, Marchlinski, and Damrauer.

Statistical analysis: Levin.

Conflict of Interest Disclosures: All authors have completed and submitted the ICMJE Form for Disclosure of Potential Conflicts of Interest. Dr. Gill is employed part-time by Novo Nordisk outside of the submitted work. Dr. Damrauer receives research support to his institution from RenalytixAI and personal consulting fees from Calico Labs, both outside the current work. No other disclosures were reported.

Funding/Support: Drs. Hyman and Marchlinski are supported by the Winkelman Family Fund in Cardiovascular Innovation. Dr. Gill is supported by the Wellcome Trust 4i Programme (203928/Z/16/Z) and British Heart Foundation Centre of Research Excellence (RE/18/4/34215) at Imperial College London. Dr Walker is supported by the Medical Research Council Integrative Epidemiology Unit. The unit is supported by the UK Medical Research Council and University of Bristol (MC_UU_00011/4 and MC_UU_00011/1). Dr. Damrauer is supported by 
medRxiv preprint doi: https://doi.org/10.1101/2020.07.26.20162339; this version posted July 29, 2020. The copyright holder for this preprint (which was not certified by peer review) is the author/funder, who has granted medRxiv a license to display the preprint in perpetuity.

All rights reserved. No reuse allowed without permission.

the Department of Veterans Affairs (IK2-CX001780). This publication does not represent the views of the Department of Veterans Affairs or the United States Government. 
medRxiv preprint doi: https://doi.org/10.1101/2020.07.26.20162339; this version posted July 29, 2020. The copyright holder for this preprint

(which was not certified by peer review) is the author/funder, who has granted medRxiv a license to display the preprint in perpetuity.

All rights reserved. No reuse allowed without permission.

\section{References}

1. January CT, Wann LS, Alpert JS, et al. 2014 AHA/ACC/HRS guideline for the management of patients with atrial fibrillation: a report of the American College of Cardiology/American Heart Association Task Force on practice guidelines and the Heart Rhythm Society. Circulation. 2014;130(23):e199-267.

2. Kirchhof P, Benussi S, Kotecha D, et al. 2016 ESC Guidelines for the management of atrial fibrillation developed in collaboration with EACTS. Eur Heart J. 2016;37(38):2893-2962.

3. Pathak RK, Middeldorp ME, Lau DH, et al. Aggressive risk factor reduction study for atrial fibrillation and implications for the outcome of ablation: the ARREST-AF cohort study. J Am Coll Cardiol. 2014;64(21):2222-2231.

4. Pathak RK, Middeldorp ME, Meredith M, et al. Long-Term Effect of Goal-Directed Weight Management in an Atrial Fibrillation Cohort: A Long-Term Follow-Up Study (LEGACY). J Am Coll Cardiol. 2015;65(20):2159-2169.

5. Benjamin EJ, Levy D, Vaziri SM, D'Agostino RB, Belanger AJ, Wolf PA. Independent risk factors for atrial fibrillation in a population-based cohort. The Framingham Heart Study. JAMA. 1994;271(11):840-844.

6. Huxley RR, Lopez FL, Folsom AR, et al. Absolute and attributable risks of atrial fibrillation in relation to optimal and borderline risk factors: the Atherosclerosis Risk in Communities (ARIC) study. Circulation. 2011;123(14):1501-1508.

7. Nabauer M, Gerth A, Limbourg T, et al. The Registry of the German Competence NETwork on Atrial Fibrillation: patient characteristics and initial management. Europace. 2009;11(4):423-434.

8. Rahman F, Yin X, Larson MG, et al. Trajectories of Risk Factors and Risk of New-Onset Atrial Fibrillation in the Framingham Heart Study. Hypertension. 2016;68(3):597-605.

9. Salehian O, Healey J, Stambler B, et al. Impact of ramipril on the incidence of atrial fibrillation: results of the Heart Outcomes Prevention Evaluation study. Am Heart J. 2007;154(3):448-453.

10. Wachtell K, Lehto M, Gerdts E, et al. Angiotensin II receptor blockade reduces newonset atrial fibrillation and subsequent stroke compared to atenolol: the Losartan Intervention For End Point Reduction in Hypertension (LIFE) study. J Am Coll Cardiol. 2005;45(5):712-719.

11. Hansson L, Lindholm LH, Ekbom T, et al. Randomised trial of old and new antihypertensive drugs in elderly patients: cardiovascular mortality and morbidity the Swedish Trial in Old Patients with Hypertension-2 study. Lancet. 1999;354(9192):17511756.

12. Haywood LJ, Ford CE, Crow RS, et al. Atrial fibrillation at baseline and during followup in ALLHAT (Antihypertensive and Lipid-Lowering Treatment to Prevent Heart Attack Trial). J Am Coll Cardiol. 2009;54(22):2023-2031.

13. Chen LY, Bigger JT, Hickey KT, et al. Effect of Intensive Blood Pressure Lowering on Incident Atrial Fibrillation and P-Wave Indices in the ACCORD Blood Pressure Trial. Am J Hypertens. 2016;29(11):1276-1282.

14. Soliman EZ, Rahman AF, Zhang ZM, et al. Effect of Intensive Blood Pressure Lowering on the Risk of Atrial Fibrillation. Hypertension. 2020;75(6):1491-1496. 
medRxiv preprint doi: https://doi.org/10.1101/2020.07.26.20162339; this version posted July 29, 2020. The copyright holder for this preprint (which was not certified by peer review) is the author/funder, who has granted medRxiv a license to display the preprint in perpetuity.

All rights reserved. No reuse allowed without permission.

15. Neeland IJ, Kozlitina J. Mendelian Randomization: Using Natural Genetic Variation to Assess the Causal Role of Modifiable Risk Factors in Observational Studies. Circulation. 2017;135(8):755-758.

16. Bhatt H, Gamboa CM, Safford MM, Soliman EZ, Glasser SP. Is there an association between the prevalence of atrial fibrillation and severity and control of hypertension? The REasons for Geographic And Racial Differences in Stroke study. J Am Soc Hypertens. 2016;10(7):578-586 e575.

17. Webb AJ, Rothwell PM. Blood pressure variability and risk of new-onset atrial fibrillation: a systematic review of randomized trials of antihypertensive drugs. Stroke. 2010;41(9):2091-2093.

18. Emdin CA, Callender T, Cao J, Rahimi K. Effect of antihypertensive agents on risk of atrial fibrillation: a meta-analysis of large-scale randomized trials. Europace. 2015;17(5):701-710.

19. Evangelou E, Warren HR, Mosen-Ansorena D, et al. Genetic analysis of over 1 million people identifies 535 new loci associated with blood pressure traits. Nat Genet. 2018;50(10):1412-1425.

20. Roselli C, Chaffin MD, Weng LC, et al. Multi-ethnic genome-wide association study for atrial fibrillation. Nat Genet. 2018;50(9):1225-1233.

21. Burgess S, Davies NM, Thompson SG. Bias due to participant overlap in two-sample Mendelian randomization. Genet Epidemiol. 2016;40(7):597-608.

22. https://data.bris.ac.uk/data/dataset/pnoat8cxo0u52p6ynfaekeigi. Accessed.

23. Burgess S, Small DS, Thompson SG. A review of instrumental variable estimators for Mendelian randomization. Stat Methods Med Res. 2017;26(5):2333-2355.

24. Gill D, Georgakis MK, Koskeridis F, et al. Use of Genetic Variants Related to Antihypertensive Drugs to Inform on Efficacy and Side Effects. Circulation. 2019;140(4):270-279.

25. Walker VM, Kehoe PG, Martin RM, Davies NM. Repurposing antihypertensive drugs for the prevention of Alzheimer's disease: a Mendelian randomization study. Int J Epidemiol. 2019.

26. Consortium GT, Laboratory DA, Coordinating Center -Analysis Working G, et al. Genetic effects on gene expression across human tissues. Nature. 2017;550(7675):204213.

27. Hemani G, Zheng J, Elsworth B, et al. The MR-Base platform supports systematic causal inference across the human phenome. Elife. 2018;7.

28. Verbanck M, Chen CY, Neale B, Do R. Detection of widespread horizontal pleiotropy in causal relationships inferred from Mendelian randomization between complex traits and diseases. Nat Genet. 2018;50(5):693-698.

29. Shim H, Chasman DI, Smith JD, et al. A multivariate genome-wide association analysis of 10 LDL subfractions, and their response to statin treatment, in 1868 Caucasians. PLoS One. 2015;10(4):e0120758.

30. Palmer TM, Lawlor DA, Harbord RM, et al. Using multiple genetic variants as instrumental variables for modifiable risk factors. Stat Methods Med Res. 2012;21(3):223-242.

31. Mitchell GF, Vasan RS, Keyes MJ, et al. Pulse pressure and risk of new-onset atrial fibrillation. JAMA. 2007;297(7):709-715. 
medRxiv preprint doi: https://doi.org/10.1101/2020.07.26.20162339; this version posted July 29, 2020. The copyright holder for this preprint

(which was not certified by peer review) is the author/funder, who has granted medRxiv a license to display the preprint in perpetuity.

All rights reserved. No reuse allowed without permission.

32. He L, Culminskaya I, Loika Y, et al. Causal effects of cardiovascular risk factors on onset of major age-related diseases: A time-to-event Mendelian randomization study. Exp Gerontol. 2018;107:74-86.

33. Hou L, Xu M, Yu Y, et al. Exploring the causal pathway from ischemic stroke to atrial fibrillation: a network Mendelian randomization study. Mol Med. 2020;26(1):7.

34. Choisy SC, Arberry LA, Hancox JC, James AF. Increased susceptibility to atrial tachyarrhythmia in spontaneously hypertensive rat hearts. Hypertension. 2007;49(3):498505.

35. Lau DH, Mackenzie L, Kelly DJ, et al. Hypertension and atrial fibrillation: evidence of progressive atrial remodeling with electrostructural correlate in a conscious chronically instrumented ovine model. Heart Rhythm. 2010;7(9):1282-1290.

36. Lau DH, Shipp NJ, Kelly DJ, et al. Atrial arrhythmia in ageing spontaneously hypertensive rats: unraveling the substrate in hypertension and ageing. PLoS One. 2013;8(8):e72416.

37. Valles E, Fan R, Roux JF, et al. Localization of atrial fibrillation triggers in patients undergoing pulmonary vein isolation: importance of the carina region. J Am Coll Cardiol. 2008;52(17):1413-1420.

38. Lalani GG, Schricker A, Gibson M, Rostamian A, Krummen DE, Narayan SM. Atrial conduction slows immediately before the onset of human atrial fibrillation: a bi-atrial contact mapping study of transitions to atrial fibrillation. J Am Coll Cardiol. 2012;59(6):595-606.

39. Vaziri SM, Larson MG, Lauer MS, Benjamin EJ, Levy D. Influence of blood pressure on left atrial size. The Framingham Heart Study. Hypertension. 1995;25(6):1155-1160.

40. Schaer BA, Schneider C, Jick SS, Conen D, Osswald S, Meier CR. Risk for incident atrial fibrillation in patients who receive antihypertensive drugs: a nested case-control study. Ann Intern Med. 2010;152(2):78-84. 


\section{Figure Legends}

\section{Figure 1: Genetic Proxies of Blood Pressure and Risk of Atrial Fibrillation}

A) Two-sample Mendelian randomization using an inverse variance weighted model was created using a genetic instrument associated with a $10 \mathrm{mmHg}$ increase in systolic blood pressure (SBP), diastolic blood pressure (DBP) and pulse pressure (PP) and risk of atrial fibrillation. B) A median weighted model was created as a sensitivity analysis. Figures are expressed as Odds Ratios (OR), 95\% Confidence Intervals (CI) and P-values for Mendelian randomization estimates.

\section{Figure 2: Genetic Proxies of Anti-Hypertensive Medications and Atrial Fibrillation Risk}

Two-sample Mendelian randomization was performed using genetic proxies for $10 \mathrm{mmHg}$ systolic blood pressure lowering by individual anti-hypertensive medication classes: A) beta-blockers and B) calcium channel blockers. Inverse variance weighted and median weighted models are presented. Figures are expressed as Odds Ratios (OR), 95\% Confidence Intervals (CI) and P-values for Mendelian randomization estimates.

\section{eFigure 1: Effect of Systolic and Diastolic Blood Pressure on AF Risk using UK Biobank Blood Pressure Genetic Instruments}

A) Two-sample Mendelian randomization using an inverse variance weighted model was created using a genetic instrument associated with a $10 \mathrm{mmHg}$ increase in systolic blood pressure (SBP) or diastolic blood pressure (DBP) and risk of atrial fibrillation. B) A median weighted model was created as a sensitivity analysis. Figures are expressed as Odds Ratios (OR), 95\% Confidence Intervals (CI) and P-values for Mendelian randomization estimates. 
Figure 1: Genetic Proxies of Blood Pressure and Risk of Atrial Fibrillation

\begin{tabular}{|c|c|c|c|c|c|c|c|c|c|}
\hline Exposure & Outcome & n SNP & Method & & & & OR & $95 \% \mathrm{Cl}$ & $\mathbf{P}$ \\
\hline SBP & Atrial Fibrillation & 399 & Inverse variance weighted & & $\longrightarrow$ & & 1.17 & {$[1.11-1.22]$} & $1 \times 10^{-11}$ \\
\hline DBP & Atrial Fibrillation & 398 & Inverse variance weighted & & 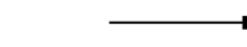 & 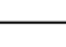 & 1.25 & {$[1.16-1.35]$} & $3 \times 10^{-8}$ \\
\hline \multirow[t]{2}{*}{ PP } & Atrial Fibrillation & 347 & Inverse variance weighted & & $=$ & & 1.1 & {$[1-1.2]$} & 0.05 \\
\hline & & & & 1.0 & $\begin{array}{lc}1.1 & 1.2 \\
\text { Odds Ratio }(95 \% \mathrm{Cl})\end{array}$ & 1.3 & & & \\
\hline Exposure & Outcome & n SNP & Method & & & & OR & $95 \% \mathrm{Cl}$ & $\mathbf{P}$ \\
\hline SBP & Atrial Fibrillation & 399 & Weighted median & & $\longrightarrow$ & & 1.18 & [1.12-1.23] & $5 \times 10^{-11}$ \\
\hline DBP & Atrial Fibrillation & 398 & Weighted median & : & $\longrightarrow$ & 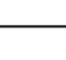 & 1.24 & {$[1.14-1.34]$} & $4 \times 10^{-7}$ \\
\hline \multirow[t]{2}{*}{ PP } & Atrial Fibrillation & 347 & Weighted median & 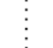 & $\longrightarrow$ & & 1.11 & {$[1.02-1.2]$} & 0.01 \\
\hline & & & & 1.0 & $\begin{array}{l}1.1 \\
\text { Odds Ratio }(95 \% \mathrm{Cl})\end{array}$ & 1.3 & & & \\
\hline
\end{tabular}


Figure 2: Genetic Proxies of Anti-Hypertensive Medications and Atrial Fibrillation Risk

\begin{tabular}{|c|c|c|c|c|c|c|c|c|c|c|}
\hline Exposure & Outcome & n SNP & Method & & & & & OR & $95 \% \mathrm{Cl}$ & $\mathbf{P}$ \\
\hline Beta-blocker & Atrial Fibrillation & 5 & Inverse variance weighted & - & $\longrightarrow$ & & & 0.613 & {$[0.463-0.811]$} & $6 \times 10^{-4}$ \\
\hline Beta-blocker & & & & 0.5 & $\begin{array}{ccc}0.6 & 0.7 & 0.8 \\
\text { Odds Ratio }(95 \% \mathrm{Cl})\end{array}$ & 0.9 & 1.0 & & & \\
\hline Exposure & Outcome & n SNP & Method & & & & & OR & $95 \% \mathrm{Cl}$ & $\mathbf{P}$ \\
\hline ium-channel blocker & Atrial Fibrillation & 20 & Inverse variance weighted & & & & & 0.657 & {$[0.57-0.758]$} & $8 \times 10^{-9}$ \\
\hline \multirow[t]{2}{*}{ cium-channel blocker } & Atrial Fibrillation & 20 & Weighted median & & $\longrightarrow$ & - & & 0.767 & [0.626-0.939] & 0.01 \\
\hline & & & & $\overline{0.6}$ & $\begin{array}{cc}0.7 & 0.8 \\
\text { Odds Ratio }(95 \% \mathrm{Cl})\end{array}$ & 0.9 & 1.0 & & & \\
\hline
\end{tabular}


eFigure 1: Effect of Systolic and Diastolic Blood Pressure on AF Risk using UK Biobank Blood Pressure Genetic Instruments

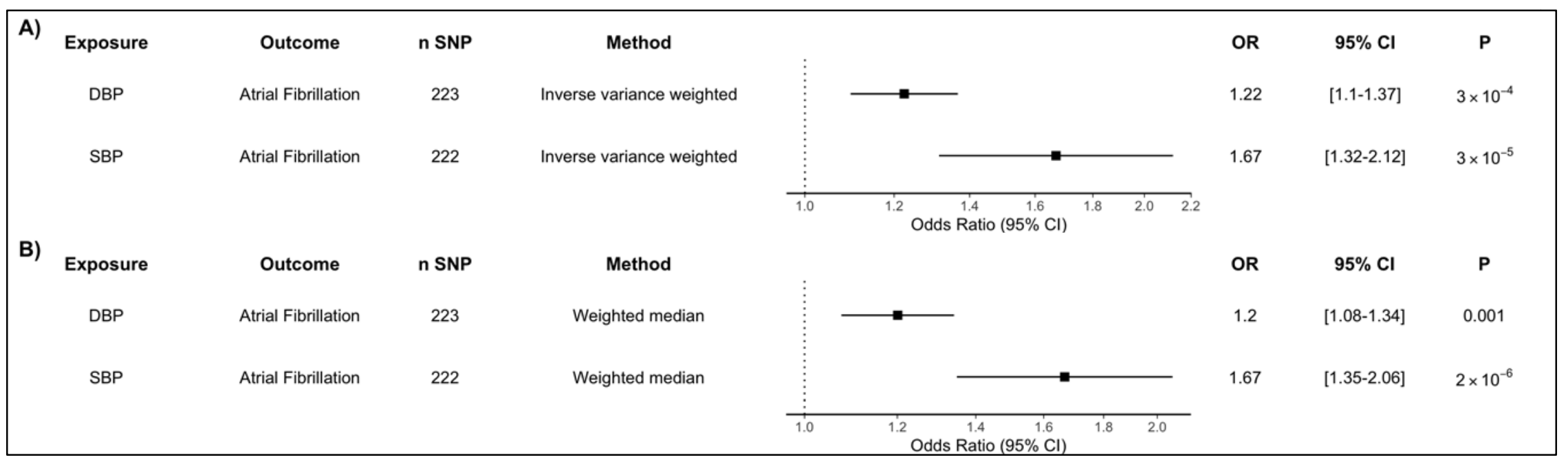

